早期乳癌術後に骨転移と鑑別が困難であった頭蓋骨血管腫の 1 例

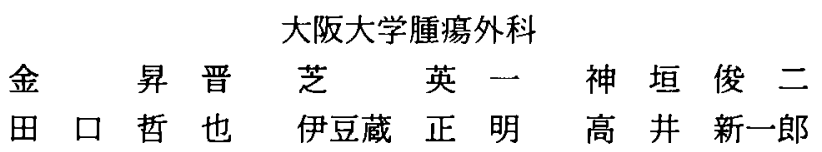

われわれは早期乳癌術後に，骨転移と鑑別が困難であった頭蓋骨血管腫の 1 例を経験 した。㭧者は37歳の女性で，右乳癌（T1aN0M0，I 期)のために乳房温存術を受けた。 術後の骨シンチで頭蓋骨に陽性像を示し，X 線およびCT 検査でも左頭頂骨に骨溶解像 を認め, 骨転移を強く疑うため局所切除術を施行した，組織学的検查では海綿状血管腫 であった，骨血管腫は稀な疾患であるが(全骨腫緜の $0.39 \%) ， M R I の \mathrm{~T} 1 ， \mathrm{~T} 2$ 強調画像 で斑紋状高信号として認められ，最近では無症候性の例が，椎体骨を中心に発見される 機会が増加している.MRI は乳癌骨転移の描出にも優れ，骨シンチで異常な像を認め確 定診断の困難な時にはMRI を考慮すべきと考える.

索引用語：骨血管腫, 乳癌, MRI

はじめに

今回，われわれは早期乳癌の術後に，骨転移と鑑別 が困難であった頭蓋骨血管腫の 1 例を経験したので報 告する.

$$
\text { 症例 }
$$

患者：37歳の家婦。

主訴: 右乳房腫瘤.

現病歴：平成 7 年 7 月乳癌検診にて右乳房に腫瘤を 指摘され 7 月 10 日に当科外来を受診した. 視触診, マ ンモグラフィー, 超音波検查, 穿刺吸引細胞診の結果, 右乳癌と診断され 8 月 4 日に手術目的にて当科入院と なった。

既往歴・家族歴：特記すべきことなし.

入院時現症：右乳房 $\mathrm{CD}$ 領域に径 $1.8 \mathrm{~cm}$ 大の弾性 硬の腫瘤を認めた. 表面は不整で, 可動性は不良であっ た. 腋窝および鎖骨上リンパ節は触知しなかった。

血液検查成績：CEA および CA15-3は正常範囲内 でその他にも特に異常は認めなかった。

画像検査：マンモグラフィーでは，右乳房 CD 領域 に径 $15 \mathrm{~mm}$ 大の不整な腫瘤を認めるも, spicula や石灰 化は認めなかった（図 1)．超音波検查でも右乳房 CD 領域に径 $20 \mathrm{~mm}$ 大の不整な腫瘤を認め, 画像検査上, 右乳癌と診断した.

1996年 5 月27日受付 1996年 8 月 8 日採用
穿刺吸引細胞診 : class V.

以上, TlaN0M0：Stage I の術前診断にて, 平成 7 年 8 月11日に乳房温存術として, lumpectomy と腋窝 リンパ節郭清術を行った。術後に放射線照射を予定し た.

病理組織検査：組織型は粘淮癌で, 腋窝リンパ節転 移は陰性であった。

ホルモンレセプター：ER，PgR は両者とも陽性.

術後経過：組織学的にも早期乳癌であることが判明 したが，術後にルーチンの骨転移検索のため骨シンチ を施行したところ，左頭蓋骨に陽性像を認め骨転移が 疑われた(図 2). 頭部単純骨 X 線では, 左頭頂骨に骨 シンチ陽性像に一致して径 $15 \mathrm{~mm}$ 大の骨溶解像を認め た (図 3)。さらに骨 CT 検查でも左頭頂骨に径 $10 \mathrm{~mm}$ 大の骨溶解像を認め(図 4), 骨転移が強く疑われるた め, 確定診断をつけるために術後70日目に当院脳神経 外科にて全身麻酔下に局所切除術を施行した。摘出し た腫瘤は径 $11 \mathrm{~mm}$ 大で，肉眼的に炎症所見が強く，骨 血管腫を疑わせた，病理組織像では，骨髄内に新生血 管が多数見られ，骨血管腫に特徴的な所見を示してい た (図 5).

\section{考 察}

骨シンチは, 単純骨 X 線検查に比べ骨のミネラルの 変化をより早期に検出することが可能なため, 現在で は骨転移の診断やフォローアップに沉用されてい 


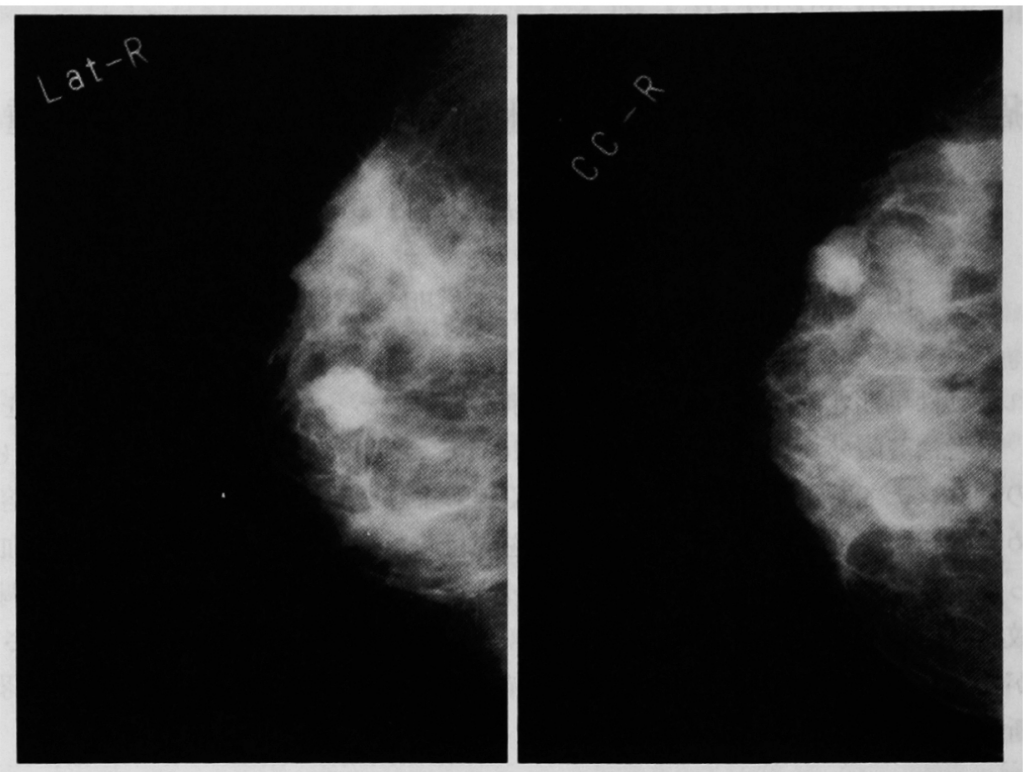

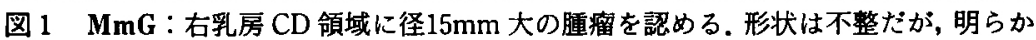
な spicula や malignant calc.は認めない.

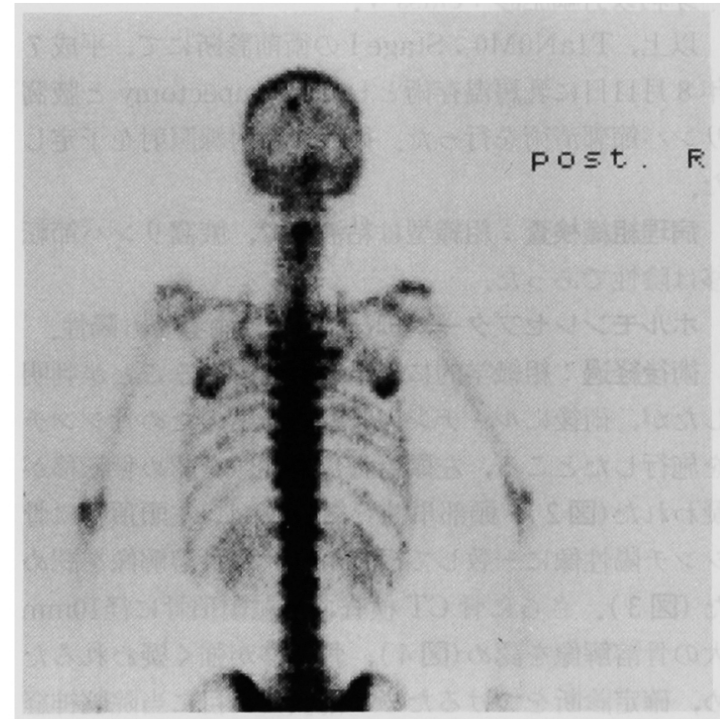

図 2 骨シンチ：左頭蓋骨に集積像を示す.

る゙.しかし，その反応は非特異的であり false positive の例が少なからず存在し，鑑別診断に苦慮することが

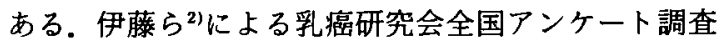
によると, 647例の乳癌初回根治術症例に骨シンチを施 行し，陽性であった例は77例 $(11.8 \%) ，$ 偽陽性は108 例 $(16.5 \%)$ ，陰性例は468例 $(71.7 \%)$ であった。こ のうち293例 (全症例の44.9\%) が骨 X 線検查や生倹を

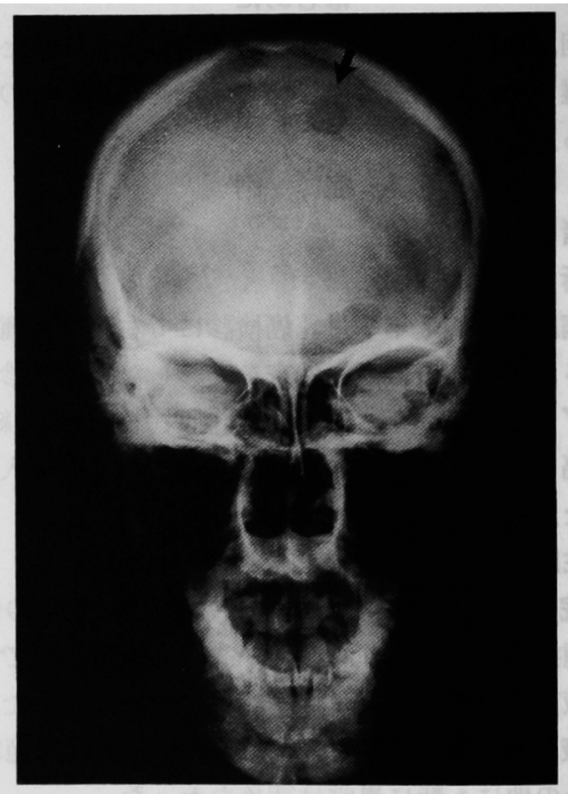

図 3 頭部単純 X 線 (正面像)：左頭頂骨に径 $15 \mathrm{~mm}$ 大の骨溶解像を認める (矢印).

受け，39例に転移が確認された。この転移例39例を病 期別にみてみると I 期 $0 / 87$ 例, II 期 $8 / 275$ 例, III期 $6 / 227$ 例, IV期25/58例であった，従って，初回根治術時とい えども 10〜20\%の症例は骨シンチ上異常所見を示し, 


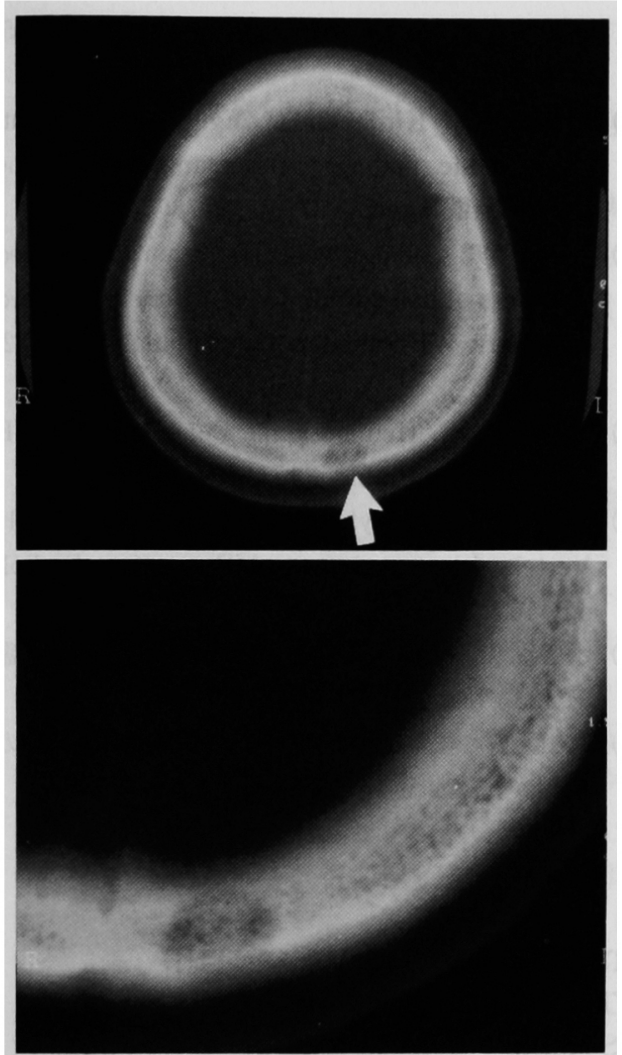

图 4 骨 CT：上段：左頭頂骨に15mm 大の骨溶解像 を認めるが(矢印)，骨皮質は保たれ不整な骨破壊は ない.下段：拉大像

そのうち実際にII期・III期の乳癌では全体の数\%に骨 転移を認める。しかし，I 期の早期癌では転移を認め る可能性は非常に少ないと言える213).

骨血管腫は新生血管から生じる発育の楥慢な良性腫 瘍で, 1972〜1991年の全国骨腫瘍患者登録によると150 例しかなく，骨腫湯全体の $0.39 \%$ 占めるにすぎな (小). 好発年齢は特になく，男性58例に対し女性92例と やや後者で多くみられる(15)。好発部位は脊椎骨と四肢 長管骨で，それぞれ全体の $32.7 \%$ と $27.3 \%$ と両者で過 半数を占める。これに対し，頭蓋骨は $4 \%$ （5例）て 少ない (表 1)。病理組織では大多数の症例が cavernous hemangioma $て ゙$, 時に capillary hemangioma みられるが，前者は主に脊椎と頭蓋骨に好発し，後者 は扁平骨と長管骨の骨幹端部に好発する4/677)。自験例 も图 5 に示したように cavernous hemangioma と診 断された，骨血管腫の臨床症状は無症状のことが多い が, 時に疼痛, 腫脹, 病的骨折などがみられ, 脊椎病

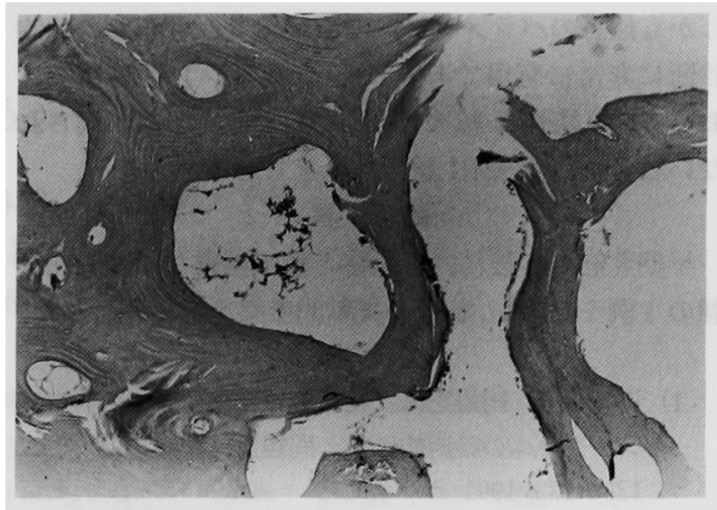

図 5 病理組織学的検査 (HE 染色, $\times 40)$ ：血球成分 を蓄え，比較的大きな腔を骨髄中に多数認め，cav ernous hemangioma と診断された。

表 1 骨血管腫150例の発生部位

\begin{tabular}{|c|c|c|c|}
\hline 単発例 & 125例 & & \\
\hline 頭蓋骨 & 5 & 骨盤 & 7 \\
\hline 頚椎 & 2 & 上肢長管骨 & 16 \\
\hline 胸椎 & 18 & 下肢長管骨 & 25 \\
\hline 腰椎 & 29 & 四肢末節骨 & 10 \\
\hline 助骨 & 6 & その他 & 7 \\
\hline 多発例 & 24例 & & \\
\hline 不明 & 1例 & & \\
\hline
\end{tabular}

変では間欠性疼痛が認められることもある．X線像で は骨吸収像を示す症例が多いが，反応性骨形成像が盛 んな例では soap bubble appearance（石けん泡状陰 影）や sun ray burst（陽光状陰影）など多彩な像を示 すことがある゙!.MRIでは T1，T2強調画像でともに斑 紋状の高信号を示し，鑑別診断に有力であるとされて いる ${ }^{788)}$.さらに, 近年の MRI の普及により無症候性の 骨血管腫が，特に脊椎を中心に発見される機会が増加 している．治療および予後に関しては，多くの症例は 病巣播爬や骨移植で治撚するが，無症状で限局性の症 例に対しては経過観察でも良いと考えられてい $3^{4) 7}$.

今までは，骨シンチで異常を認めた時には，単純骨 $\mathrm{X}$ 線検查, 骨 $\mathrm{CT}$, 生検などが施行されてきた。しかし, 骨 CT は骨破壊や仮骨変化の観察には有用であって も，腫瘍と骨髄のコントラストがつきにくく，腫瘍の 描出や広がりの検出には劣る早10)。これに対し骨 MRI は,コントラスト分解能に優れ腫瘍の検出感度が高く, 
しかも任意のパラメーターで観察でき，骨病変の質的 診断に非常に有用である ${ }^{9110)}$. 今後骨シンチ陽性例に おいて, 単純骨 X 線検査, 骨 CT で確定診断が得られ ない場合は，骨 MRI を行うべきであると考える。

$$
\text { 結 語 }
$$

早期乳癌の術後に, 骨転移と鑑別困難な頭蓋骨血管 腫の 1 例を経験し,若干の文献的考察を加え報告した。

$$
\text { 文献 }
$$

1）川崎幸子，田邉正忠：乳癌の骨転移に対する骨シ ンチグラムの診断的価値と問題点. 乳癌の蹦 6 : $125-132,1991$

2）伊藤安彦, 金田浩一, 津屋 旭：乳癌初回手術時に おける骨・肝シンチダラフィーの評価。癌の臨 24 : 1113-1121, 1978

3) Lee $\mathrm{YN}$ : Bone scanning in patients with early breast carcinoma : Should it be a routine staging procedure? Cancer $4: 486-495,1981$

4）須田昭男：血管種。富田勝郎 編集，新図説臨床整
形外科講座, No 13,メジカルピュー社, 東京, 1995, p170-171

5) Agnoli AL, Kirchhoff D, Eggert H: Roent genographic findings in hemangioma of the skull. Radiologe $18: 37-41,1978$

6) Daniel W: Benign vascular tumors and allied disorders of bone. Radiology of Bone and Allied Disorders. WB Saunders Co. Philadelphia, 1982. p660-705

7) Huvos AG: Hemangioma. Bone Tumors. WB Saunders Co, Philadelphia, 1991, p553-562

8) Ross JS, Masaryk TJ, Modic MT, et al: Vertebral hemangiomas; MR imaging. Radiology $165: 165-169,1987$

9）水谷弘和，大場 党：骨転移の MRI。乳癌の臨 $6: 125-132,1991$

10）武田元博, 松本 恒, 大内憲明他：乳癌骨転移の MRI. 乳癌の臨 6:125-132, 1991

\title{
A CASE OF EARLY BREAST CANCER WITH A HEMANGIOMA OF THE SKULL WHICH WAS DIFFICULT TO DIFFERENTIATE FROM BONE METASTASIS
}

\author{
Shoushin KIM, Eiichi SHIBA, Shunji KAMIGAKI, Tetsuya TAGUCHI, \\ Masaaki IZUKURA and Shin-ichiro TAKAI \\ Department of Surgical Oncology, Osaka University Medical School
}

We experienced a case of early breast cancer with a hemangioma of the skull, which was diffisult to differentiate from bone metastasis. A 37-year-old woman underwent a breast conservative surgery for a right early breast cancer (TlaN0M0, Stage I). Bone scintigraphy after the operation revealed an uptake in the skull, and both X-ray and CT scan showed an osteolytic change in the left occipital bone. The local excision was performed to determine whether it was bone metastasis. Histological examination showed cavernous hemangioma. Hemangioma of bones is a rare entity representing $0.39 \%$ of all bone tumors. However, asymptomatic hemangiomas, especially in the vertebral lesions, are increaseingly discovered by MR imaging, because they are recognazed as a mottled high intensity in T1- and T2-weighted MR images. As MR imaging is also very useful to detect bone metastasis in patients with breast cancer, it should be done to evaluate a suspected lesion in bone scintigraphy. 